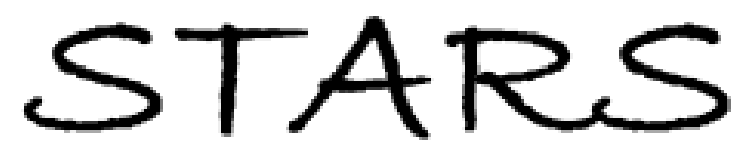

University of Central Florida

STARS

$1-1-1969$

\title{
Functional Model Of Memory Based On Physiological And Verbal Learning Data
}

\author{
J. Peter Kincaid
}

Find similar works at: https://stars.library.ucf.edu/istlibrary University of Central Florida Libraries http://library.ucf.edu

This Research Report is brought to you for free and open access by the Digital Collections at STARS. It has been accepted for inclusion in Institute for Simulation and Training by an authorized administrator of STARS. For more information, please contact STARS@ucf.edu.

\section{Recommended Citation}

Kincaid, J. Peter, "Functional Model Of Memory Based On Physiological And Verbal Learning Data" (1969). Institute for Simulation and Training. 100. https://stars.library.ucf.edu/istlibrary/100

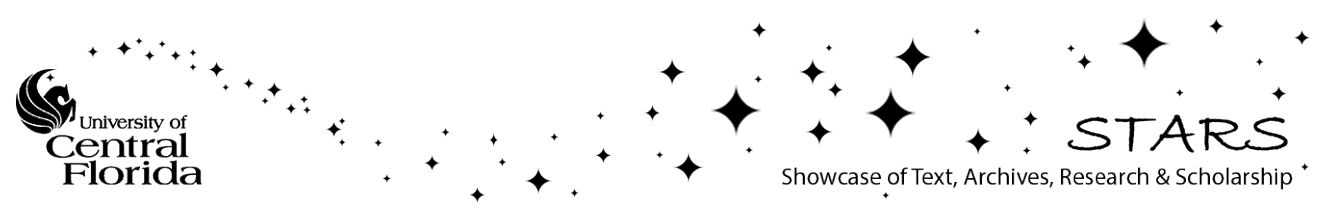


A FIRI,TR-68-16

\title{
A FUNCTIONAL MODEL OF MEMORY BASED ON PHYSIOLOGICAL AND VERBAL LEARNING DATA
}

\author{
J. PETER KINCAID
}

TECHNICAL REPORT AFHRI, TR-68 16

JUNE 1969

This document has been approved for public release and sale; its distribution is unlimited.

AIR FORCE HUMAN RESOURCES LABORATORY AIR FORCE SYSTEMS COMMAND WRIGHT-PATTERSON AIR FORCE BASE, OHIO 
AFHRL-TR-68-16

\section{A FUNCTIONAL MODEL OF MEMORY BASED ON PHYSIOLOGICAL AND VERBAL LEARNING DATA}

J. PETER KINCAID

This document has been approved for public release and sale; its distribution is unlimited. 
AFHRL-TR-68-16

\section{FOREWORD}

This report was prepared by the Personnel and Training Requirements Branch, Training Research Division, Air Force Human Resources Laboratory, Wright-Patterson Air Force Base, Ohio. The effort was accomplished in support of AFHRL Project 7907, "Research on Human Learning and Motivation." This report was written during the period of June 1968 through August 1968.

The author is grateful for the guidance and suggestions provided by Dr. William A. Johnston, Human Performance Laboratory, Ohio State University, under whose direction the report was prepared as a special research project. The critical reading of the draft manuscript by Mr. Jerry Emory of PhilcoFord Corp. is also acknowledged.

This report was submitted by the author December 1968.

This technical report has been reviewed and is approved.

GORDON A. ECKSTRAND

Chief, Training Research Division

Air Force Human Resources Laboratory 


\begin{abstract}
This report presents a functional model of memory based on verbal learning and physiological data. These diverse empirical data are used to describe several basic mechanisms of memory including: (a) separate mechanisms for short-term memory and for long-term memory; (b) the initiation of long-term memory by short-term memory; (c) the properties of short-term memory including autonomous decay, distortion by interference, and a limited capacity; (d) the properties of long-term memory including a consolidation process dependent upon ribonucleic acid (RNA) and enzymes, and a very large capacity; (e) the functional grouping of items in long-term memory; and ( $f$ ) consolidated (long-term) memories that are reactivated, being brought back into short-term memory. Time courses of these events are described.
\end{abstract}

The ultimate benefit of a detailed knowledge of the mechanisms of memory is to help us to better understand how humans learn. This report describes how mnemonic techniques work and presents suggestions about how to improve memory training. 
AFHRL-TR-68-16

TABLE OF CONTENTS

SECTION

PAGE

I INTRODUCTION

1

II THREE CURRENT MODELS OF MEMORY

3

III EVIDENCE THAT SHORT-TERM MEMORY

INITIATES LONG-TERM MEMORY

7

IV THE NATURE OF SHORT-TERM MEMORY

12

V CONSOLIDATION OF LONG-TERM MEMORY

15

$\begin{array}{ll}\text { VI THE MORPHOLOGY OF LEARNING } & 18\end{array}$

VII THE MECHANISMS OF MNEMONIC DEVICES

VIII A FUNCTIONAL MODEL OF MEMORY 25

REFERENCES

28 


\section{ILLUSTRATIONS}

\section{FIGURE}

1. The Primary and Secondary Memory System of Waugh and Norman (1965)

2. Peterson's (1966) Model of Memory 5

3. Halstead and Rucker's (1968) Model of Memory 5

4. The Step-Down Apparatus Used by Kincaid (1967) 8

5. A Gradient of Retrograde Amnesia Produced by Electroconvulsive Shock (after Quartermain, et al, 1965)

6. Differential Recall of Nonsense Syllable Paired Associates Over Time as a Function of Arousal Level (after Kleinsmith and Kaplan, 1964)

7. Differential Recall of Paired Associates Over Time as a Function of Arousal Levels, (after Batten, 1967)

8. Retention Curves Obtained From the Distractor and Probe Techniques (after Keppel, 1965)

9. Temporal Gradients of Retrograde Amnesia Produced by Metrazol or Electroconvulsive Shock (Kincaid, 1968, Figure 1, pg 329)

10. Halstead and Rucker's (1968) Molecular Explanation for Long-Term Memory

11. Changes in Synapses After Learning and the Administration of Drugs (after Deutsch, 1969)

12. A Functional Model of Memory 


\section{SECTION I}

\section{INTRODUCTION}

This report brings together verbal learning and physiological data bearing on a two-stage model of memory. Most recent models of memory have postulated a two-stage process involving separate mechanisms of short-term memory (STM) and long-term memory (LTM). Evidence is presented to indicate that these two stages of memory are differentially affected by the same experimental manipulation. However, these models have been primarily based on verbal learning data which mostly covers STM (Peterson, 1966; Waugh and Norman, 1965) or physiological data dealing mostly with the consolidated or long-term component of memory (Halstead and Rucker, 1968). These models are basically similar indicating that they describe the same processes (i.e., two stages of memory based on distinct behavioral and physiological processes).

This report has several purposes including: (a) to build a model of memory based on both physiological and verbal learning data; and (b) to give an example of the use of-principles of memory to improve human learning capability.

Melton (1963) in his classic paper asks several questions that any model of memory should consider. He discussed the implications of research in the area of short-term for a general theory of memory. The report states that there are three fundamental processes involved in the behavior of remembering including trace formation, trace storage, and trace utilization. Pertinent questions include: Is there an autonomous decay of memory over time? Is there an autonomous enhancement over time? What is the morphology of memory at the molecular level? Are there two processes of memory, and if so, what is their nature? These questions are dealt with in this paper. Melton also cautioned that the data which is said to bear on memory storage is derived from the retrieval process. Events affecting retrieval such as stimulus fluctuation (Estes, 1955) might not affect storage. A learning change is distinct from a retention change. 
The most important question of all is: How can a knowledge about the mechanisms of memory help us to understand and improve the learning process? One intent of this report is to build a framework from the current research literature in order to help answer that question. The organization of the major headings of this report were derived with this in mind. The first section includes a description of three current models of memory. Two are based on the verbal learning literature and the third on physiological and biochemical data. They are presented in their bearest form; corroborating evidence for each theory follows. The second section deals with evidence that short-term memory initiates long-term memory - a premise of each of three models presented. The third and fourth sections deal with autonomous decay of shortterm memory over time and consolidation of long-term memory over time. The fifth section briefly presents evidence bearing on the morphology of memory mechanisms, chiefly the contributing of biopsychologists. The sixth section is an attempt to explain, on the basis of some very recent research, how mnemonics devices work. It is an effort to bridge the gap between theoretical models derived from basic research and practical uses of these models. Finally, the author's own model of memory is presented. 


\section{SECTION II}

\section{THREE CURRENT MODELS OF MEMORY}

This section contains a brief summary of three recent models of memory. Two of these are based on verbal learning data (Waugh and Norman, 1965; Peterson, 1966). The third is drawn from research dealing with the molecular basis of memory, chiefly the role of ribonucleic acid (RNA) and deoxyribonucleic acid (DNA) in long-term memory (Halstead and Rucker, 1968). One purpose of presenting these models is to give the reader a quick overview of several different points of view. The empirical evidence on which these theories are based and some of their ramifications are presented in later sections. Another purpose of presenting these models is to show some of their obvious similarities. All include several different stages of memory characterized by different behavior and/or physiological operations and the time courses of these stages are quite similar. All purpose that memory of an item can be carried by two stages at once, that is, the stages overlap. The differences in terminology used by various theorists is not very important. Peterson's (1966) "short-term" memory, Halstead and Rucker's (1968) "dynamic stage," and Waugh and Norman's (1965), "primary memory system" are all functionally equivalent. Similarly, "long-term memory," and "secondary memory system" describe the same process. Halstead and Rucker (1968) have broken "long-term memory" into two phases "intermediate" and "consolidated." Their work has concentrated on these later phases of memory.

Waugh and Norman's (1965) model is presented in Figure 1 and is based on data derived from three verbal learning methodologies: (a) free recall, (b) probe digit, and (c) paired associates. There are three basic points of this model. The first is that unrehearsed verbal material is lost from memory (forgotten), not because of decay, but because of interference by later items in a series. The capacity of the primary memory system is quite limited. Second, rehearsal may transfer an item to the larger and more stable secondary memory system. Third, a recently perceived item may be retained in both stores at the same time. 


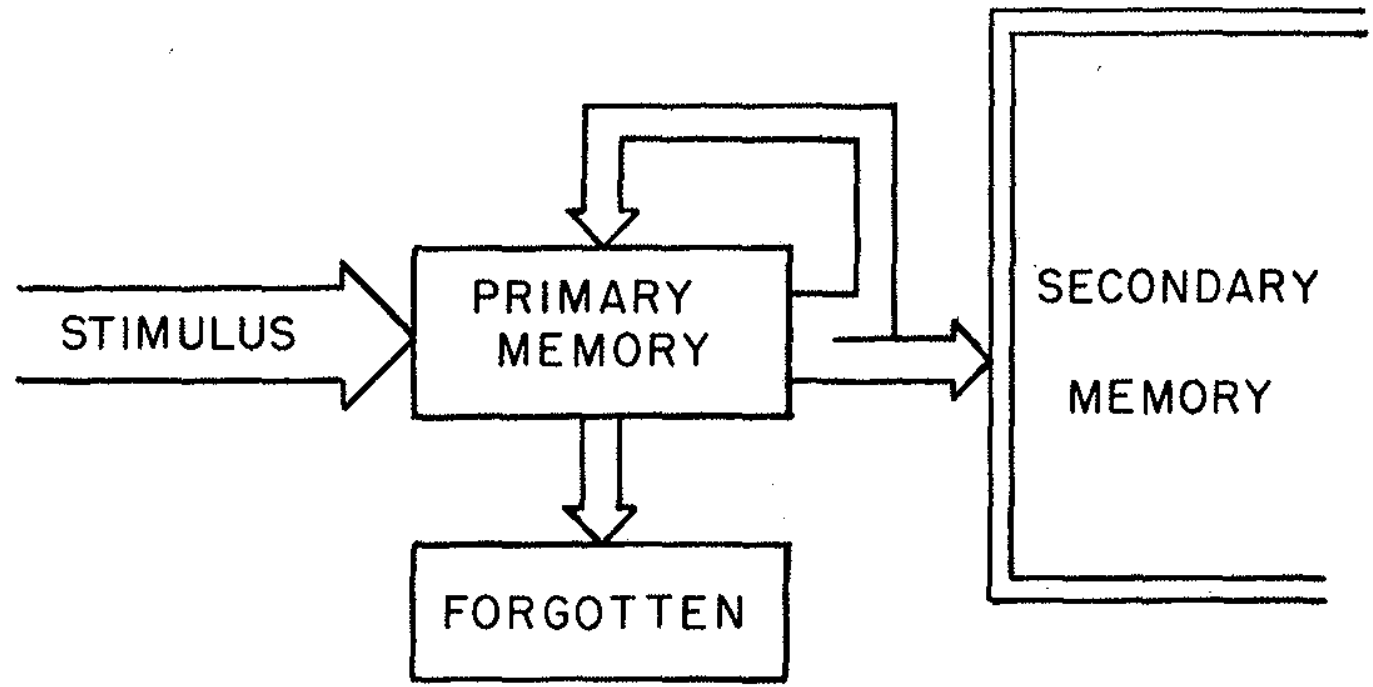

Figure 1. The primary and secondary memory system drawn from Waugh and Norman (1965). Verbal items enter primary memory (short-term) where they are either rehearsed or forgotten. Rehearsed items are given a subsequent opportunity to enter secondary (long-term) memory.

Peterson's (1966) model is presented in Figure 2. He postulates two phases of memory, short and long-term, based on data he has obtained using the paired associates verbal learning techniques. Interpolated activity (counting backwards by 3's) was interposed for a given period of time from learning to recall. The object was to reduce the opportunity for rehearsal. This technique introduced by Peterson and Peterson (1962) was the breakthrough that gave impetus to the current interest in the study of short-term verbal learning. The short-term memory component (labeled the dynamic phase in Figure 2) falls off rapidly dependent to some extent on interference. The long-term memory component (labeled the intermediate phase) builds gradually and is less influenced by interference. The asymptote of the intermediate phase function coincides with the curve representing total retention. Short-term memory is essentially over within about 5 to 10 seconds. Peterson (1966) concludes that there are separate mechanisms for short and long-term memory. His experimental analysis of retention extends less than one minute after stimulus presentation.

Halstead and Rucker's (1968) model is presented in Figure 3. It includes three phases, dynamic, intermediate, and consolidated. The first two of these 


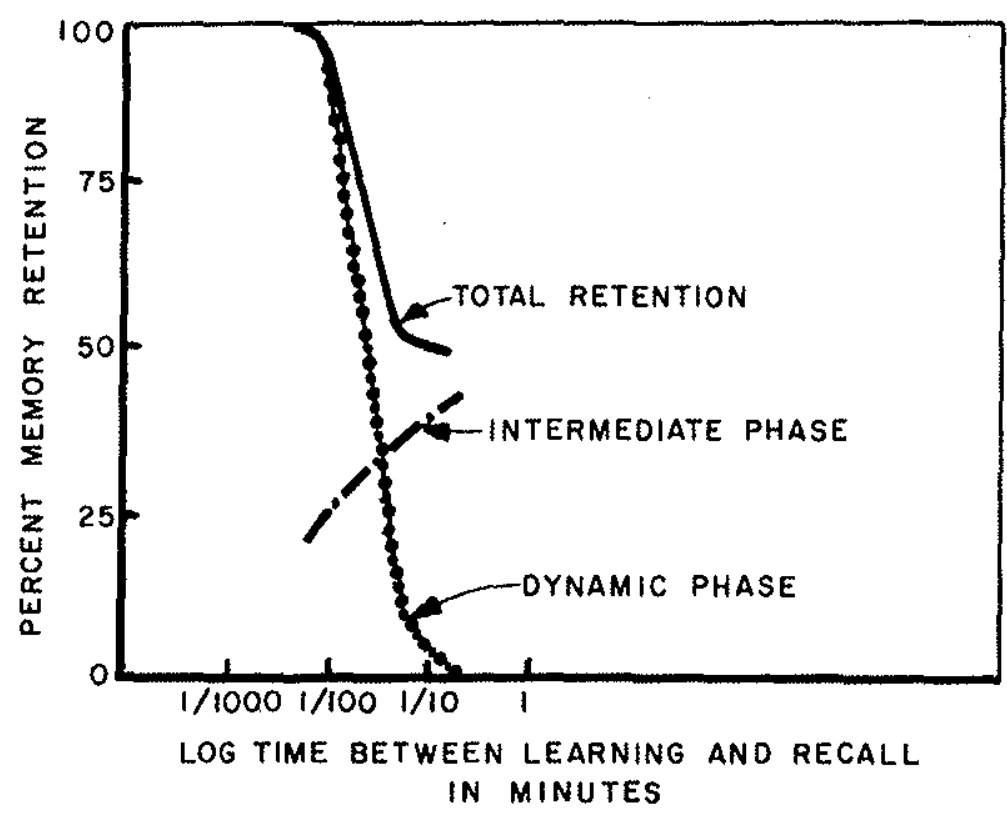

Figure 2. Peterson's (1966) model of memory (redrawn from Figure 6, page 204) includes two phases of memory: dynamic and intermediate. Note the similarity to the Halstead-Rucker model (Figure 3) 。

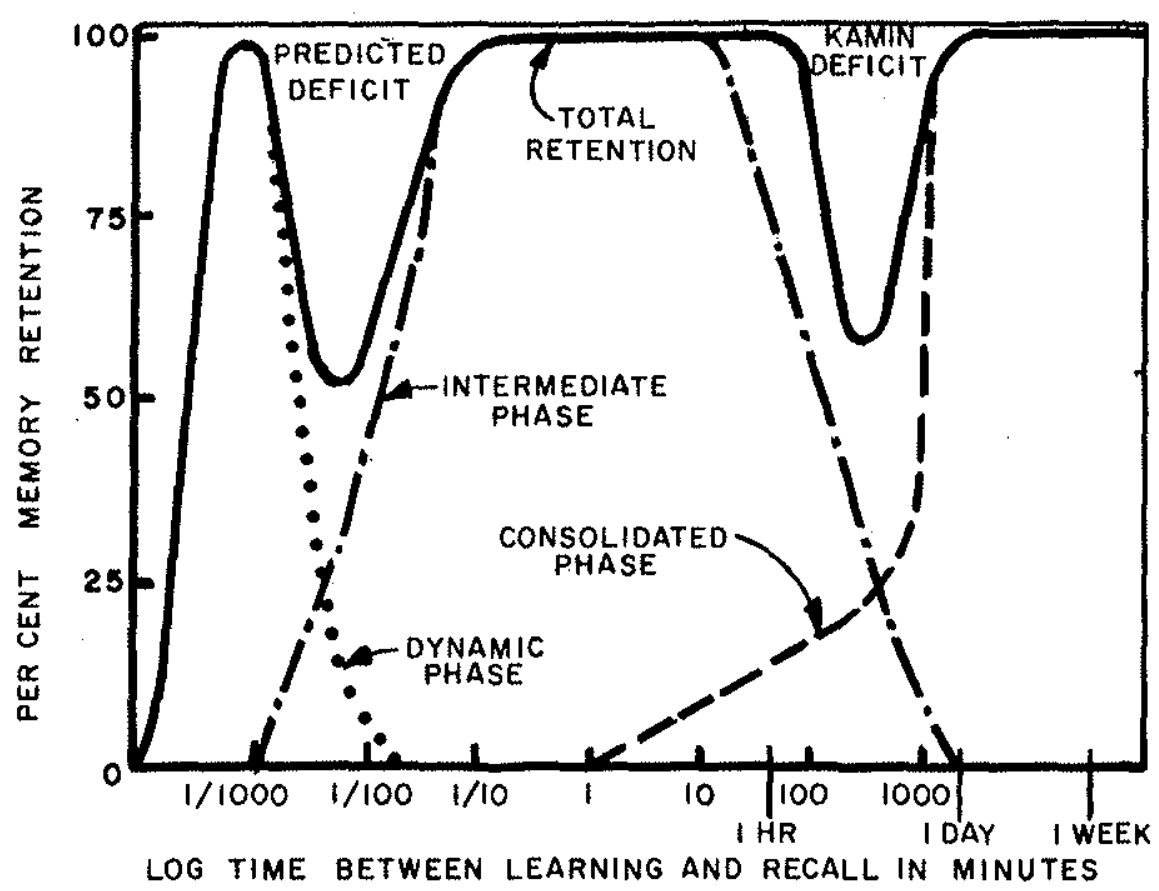

Figure 3. Halstead and Rucker's (1968) model of memory (redrawn from page 67). It includes three phases: dynamic, intermediate, and permanent. Deficits in memory are predicted in intervals between successive phases. 
are comparable to Peterson's (1966) two stages. Halstead and Rucker's (1968) model is based largely on biochemical changes that occur within the individual cell during the consolidated phase. These changes are responsible for more-orless permanent retention. The intermediate phase is said to be responsible for intracellular changes that occur during the consolidated phase. Activity between neurons is the mechanism of this intermediate phase. It is unclear whether or not the within cell changes modify the sensitivity of the firing between synapses according to the Halstead and Rucker (1968) model. However, evidence presented by Deutsch (1968) concerning the action of acytylcholine on firing neurons and its importance to long-term memory will be considered later. Krech (1968) speculates that enzyme changes as well as growth of neurons, mediated by RNA, both contribute to learning and long-term memory.

Note the similarity of the time courses of Peterson's (1966) model and the first two phases of Halstead and Rucker's (1968) model (Figures 2 and 3). One is tempted to say that they describe the same thing, and indeed, this is probably the case. The Peterson graph has been redrawn with a long time scale to facilitate comparison. But such a statement is tenuous. For one thing, Peterson's data was based on verbal retention over very short intervals. Halstead and Rucker used biochemical and behavioral data based on longer term retention by rat subjects. Furthermore, it is not precisely clear how Halstead and Rucker (1968) derived the curve representing the dynamic phase of memory.

In summary, the three models described above have the following things in common: (a) short and long-term memory are viewed as separate processes; (b) short-term memory has a limited capacity and loses items over time (due to decay and/or interference); and (c) long-term memory has a large capacity and information is stored in a more stable manner. 


\section{SECTION III \\ EVIDENCE THAT SHORT-TERM MEMORY INITIATES LONG-TERM MEMORY}

Several types of evidence indicate that some process taking place soon after a learning event is responsible for a permament memory trace. This early process (short-term memory) can be manipulated in several ways to produce changes in long-term memory. These experimental manipulations must take place within a period of seconds or minutes (during the period of short-term memory) to affect long-term memory. Two types of evidence supporting this include: (a) the time course (or temporal gradient) during which electroconvulsive shock (ECS) produces retrograde amnesia; and (b) the temporal gradient of retention produced by arousal at the time of learning. Implicit in this analysis is the assumption that short-term memory and longterm memory are separate processes based on separate mechanisms - if an experimental manipulation at the time of learning produces different behavioral effects at different intervals after learning, this is evidence for separate memory processes.

Electroconvulsive shock (ECS) administered shortly after one trial learning produces a decrement in the ability of the subject to perform what was learned. The method frequently used and one which the author has used (Kincaid, 1967, 1968) is illustrated in Figure 4. It is an apparatus which can be used to produce learning in one trial.

The important finding is the rather brief temporal gradient of retrograde amnesia that is produced by the administration of ECS soon after a learning event. Within a particular experimental context and given a certain species and ECS parameters, a rather clean gradient of retrograde amnesia is generally obtained. (Chorover and Schiller, 1966; Quartermain, Paolino and Miller, 1965). This is illustrated in Figure 5.

As ECS is administered at a longer time following learning event, its ability to produce retrograde amnesia is reduced until at a certain period after learning it has no permanent effect on the memory of the learned event. Furthermore, several investigators have demonstrated that this amnesia is still in effect 


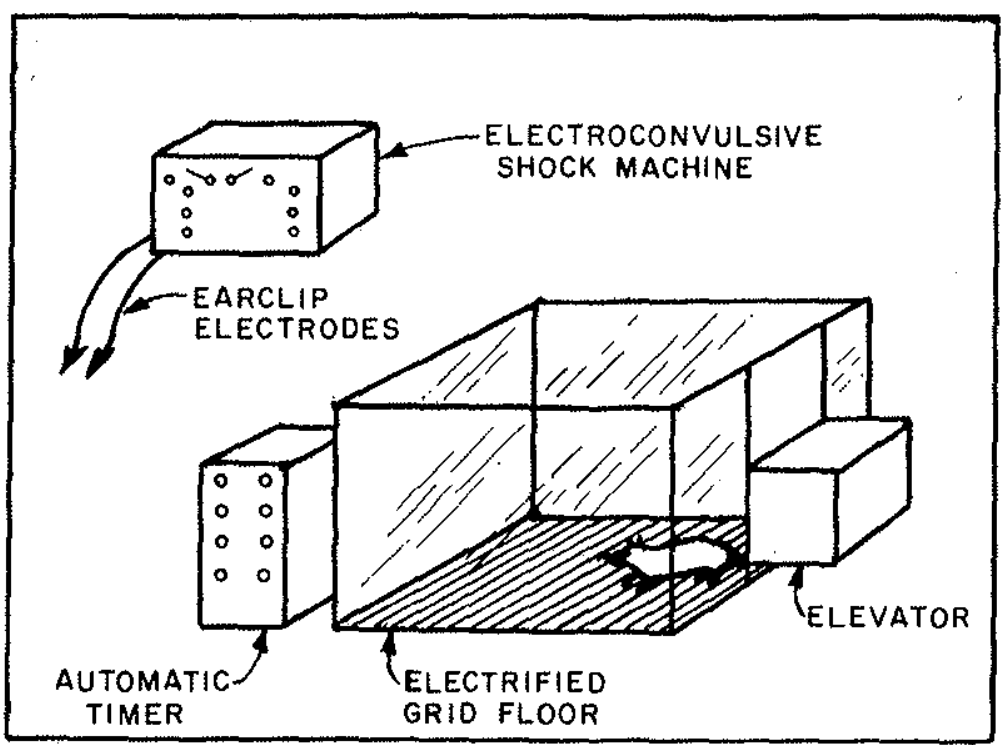

Figure 4. The step down apparatus used by Kincaid (1967). As the platform is lowered, the rat steps off onto the grid floor. A powerful shock in the large compartment teaches the rat not to step into the large compartment again. If ECS is applied soon after, it will produce amnesia for the punishment and the rat will step off the platform when tested later.

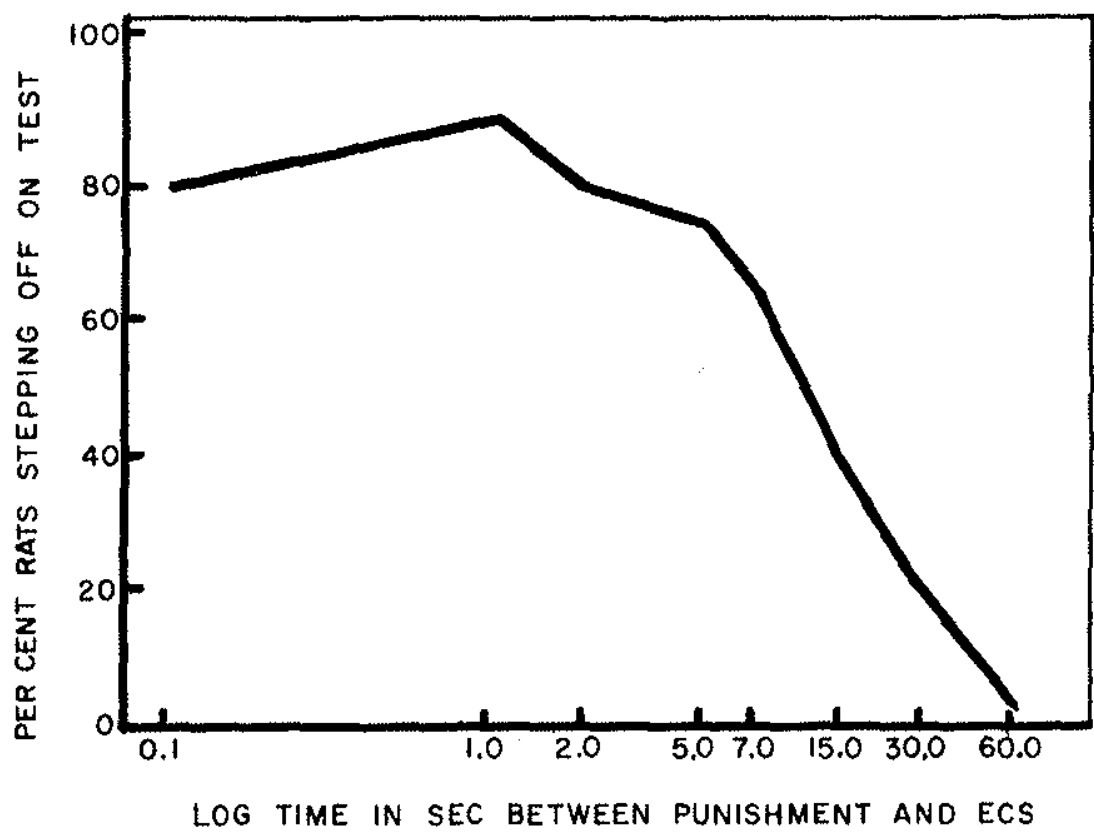

Figure 5. A gradient of retrograde amnesia produced by Electroconvulsive Shock. Note the diminished effect of the ECS when it follows step down training by thirty seconds. Control groups are not shown (redrawn from Quartermain, Paolino, and Miller, 1965, Figure 1, pg 1117). 
several weeks or a month later (Chevalier, 1965; Kincaid, 1967). Other investigators have shown that the memory of the learned event partially returns (Misanin, Miller and Lewis, 1968).

A possible explanation of these findings is that some process underlying short-term memory such as perseveration of bioelectrical activity in the central nervous system is responsible for the initiation of the permanent memory trace (long-term memory). Consequently, ECS must be administered soon after learning to disrupt the initiation of the permanent memory trace. The downward slope of the retrograde amnesia curve illustrated in Figure 5, reflects the growing long-term trace; retrograde amnesia becomes less with time because the long-term trace is becoming stronger at the same time. This explanation is precisely in accord with the Halstead and Rucker (1968) model.

Parallel evidence from the arousal data is provided by such work as that of Kleinsmith and Kaplan (1964). They demonstrated that if a subject learned verbal material in an aroused state then recall of that material was inferior to material learned under low arousal state when it had to be recalled immediately. However, recall for the high arousal condition was superior one week after learning. Arousal was determined by a galvanic skin response (GSR) reading at the time of learning. These results are particularly impressive because retention of a particular item was related to the GSR of the subject at the time he learned the item (see Figure 6).

The explanation offered by Kleinsmith and Kaplan (1964) is compatible with the explanation of the ECS data that is offered above.Perseveration of the high arousal material is too rapid to permit good immediate recall; however, it initiates the formation of a very strong permanent trace so that recall is very good at a later time. Berlyne, et al, (1966), using white noise to produce arousal obtained somewhat the same resuits although their data are not as clean. Batten (1967), using drugs to produce various states of arousal has produced results that are remarkably similar to those of Kleinsmith and Kaplan (1964). Note the similarity of the time courses found in these two studies (Figures 6 and 7). 


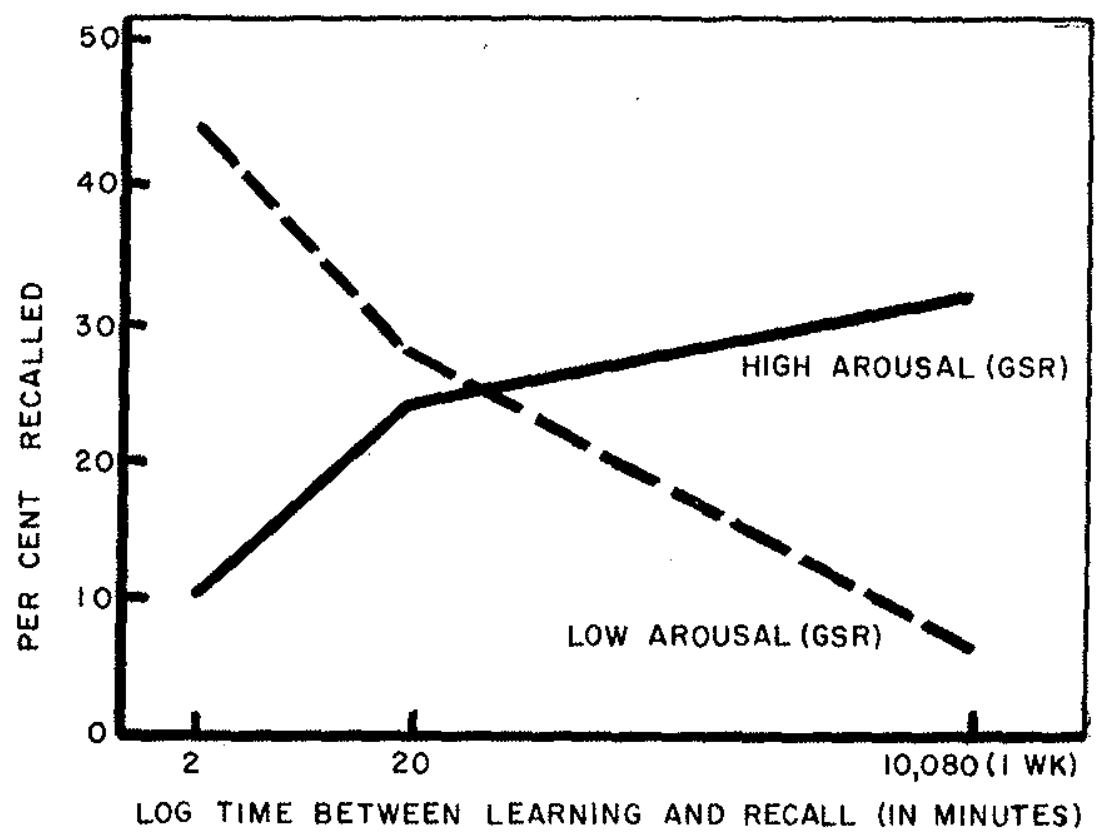

Figure 6. Differential recall of nonsense syllable paired associates over time as a function of arousal level. "Arousal level", was defined according to the subject's Galvanic Skin Response at the time of learning of a particular item (redrawn from Kleinsmith and Kaplan, 1964, pg 125, Figure 1) .

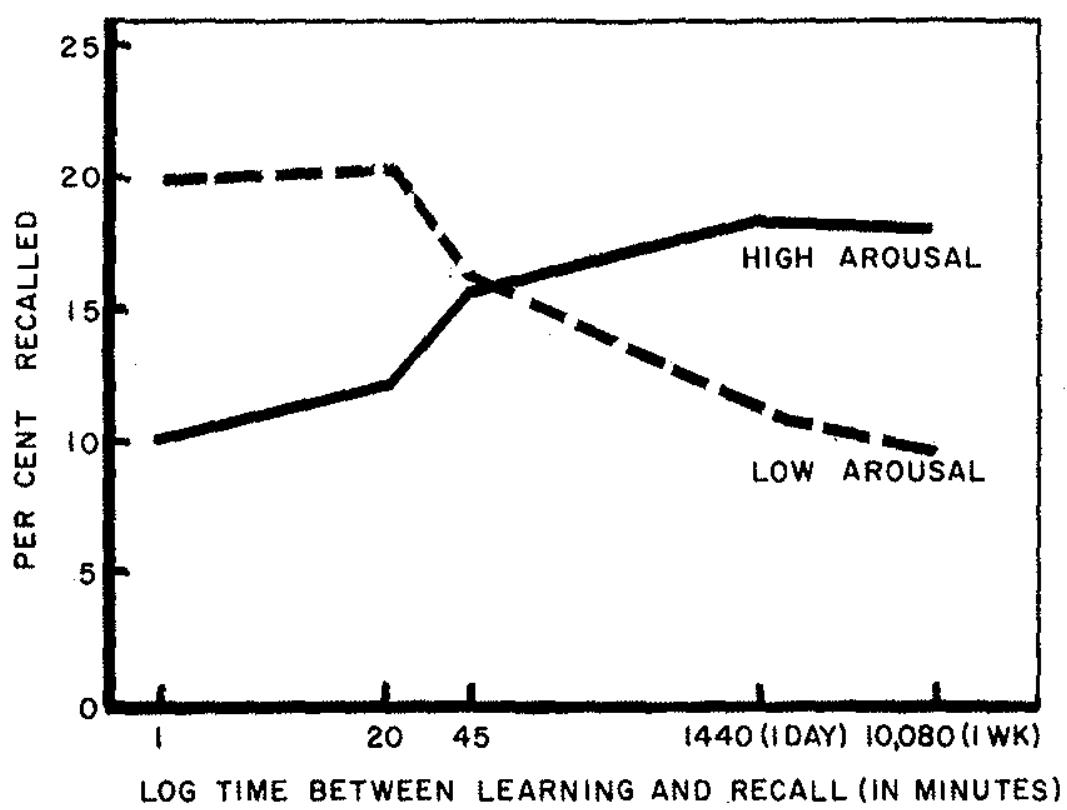

Figure 7. Differential recall of paired associates over time as a function of arousal levels. "Arousal level" was manipulated by the use of drugs. One hundred $\mathrm{mg}$ of phenobarbital was given to the low arousal group and $10 \mathrm{mg}$ of dexedrive plus instructions to create arousal were given to the high arousal group (redrawn from Batten, 1967, pg 1057, Figure 1). 
AFHRL-TR-68-16

The similarity in the explanations offered for the ECS data and for the arousal data are significant because of the vastly different methods used to gather those data. Quartermain, Paolino, and Miller (1965) used rats and a stepdown apparatus to collect their ECS data. Kleinsmith and Kaplan (1964) used human subjects learning verbal material to collect their arousal data. In addition, the temporal gradients produced by studies in both areas are consistent (or at least not inconsistent). In both cases, short-term memory is affected by the several experimental manipulations within two minutes after learning. 


\section{SECTION IV}

\section{THE NATURE OF SHORT-TERM MEMORY.}

The preceding section contained evidence that short and long-term memory are separate processes. This section deals with the mechanisms of short-term memory. That short-term memory is a rapidly deteriorating process is illustrated by the empirical curve of Peterson and Peterson (1962). This section contains evidence that both autonomous decay and interference contribute to this deterioration. Also treated are the mechanisms of storage and retrieval in short-term memory and the capacity of short-term memory. Estimates of this capacity range from two to three bits depending upon the particular sensory modulity used for sensory input (Miller, 1956). However, several conditions can alter the apparent capacity in bits. For example, Alluisi, et al (1964) found that the capacity of short-term memory for processing highly compatible stimulus-response ( $\mathrm{S}-\mathrm{R}$ ) pairs is much higher than the capacity for incompatible pairs. Likewise, the capacity for processing unfamiliar material or material that is difficult to discriminate is lower than the capacity for processing familiar material or material that is easy to discriminate. A substitution of Miller's (1956) "chunks" for bits resolves some of this inconsistency and gives some assurance that the capacity of short-term memory is relatively fixed. We do not have a completely adequate definition of a "chunk" of information.

Nonetheless, Waugh and Norman's (1965) model makes a good case for a fixed capacity for short-term memory (see Figure 1). This model depicts a limited shortmterm memory capacity with items being lost by interference. Rehearsal accounts for items reaching long-term memory. They argue that new items displace previous items from short-term memory. Murdock (1968) proposes that new items compress, rather than displace, previous items in short-term memory. He found that subjects retained less information per item with longer lists but the total amount of stored information remained constant. This finding was based on a variety of techniques including sequential probe, positional probe, reverse probe, ordered probe, and cued recall. 


\section{AFHRL-TR-68-16}

An examination of a great many short-term memory, verbal learning experiments suggests that interference contributes to the rapid deterioration in short-term memory. For example, Wickelgren (1966) describes "associative intrusions" that occurred between two letters in a nine letter list that followed the same letter. That is, " $t$ " might have appeared twice, followed in one case by " $\mathrm{m}$ ", and in another case by " $\mathrm{n}$." During recall, " $\mathrm{m}$ "' and " $\mathrm{n}$ " would frequently be substituted for one another. Kepple and Underwood (1962), Wickens, Born, and Allen (1963), Loess (1964) and Murdock (1966) have all reported that inhibition is an important factor in short-term memory. The first three studies dealt with proactive inhibition and the last with retroactive inhibition.

If decay is a factor in the deterioration of short-term memory, then some part of the short-term memory function should not be accounted for by interference. Murdock (1967) and Kepple (1965) have obtained evidence that interference and decay contribute to the deterioration of short-term memory at different times. Both used Peterson's method and filled the interpolated interval of activity with either unrelated, nonlearning materials (distractor technique) or with categorically related learning materials (probe technique). Results indicated that interference is the prime factor in the deterioration of short-term memory for the first four or five seconds after stimulus exposure but that its effect becomes much less during the later portion of the short-term memory process (5 - 15 seconds). Kepple's (1965) results are illustrated in Figure 8. Note that beyond four seconds, the probe and distractor functions are parallel. It is during the first four seconds after stimulus presentation that interference in short term memory is produced by intrusion of interpolated learning activities involving similar learning materials.

That decay is not an important factor during the first few seconds of shortterm memory is supported by the results obtained by Quartermain, Paolino, and Miller (1965). These results are depicted in Figure 2. The temporal gradient of retrograde amnesia does not fall off rapidly until five seconds have elapsed from a training trial to the administration of the amnesic agent (electroconvulsive shock). In this situation, five seconds had to pass before short-term memory began to initiate long-term memory (which is immune to the effects of the ECS. The gradual initiation of long-term memory and the decay of 


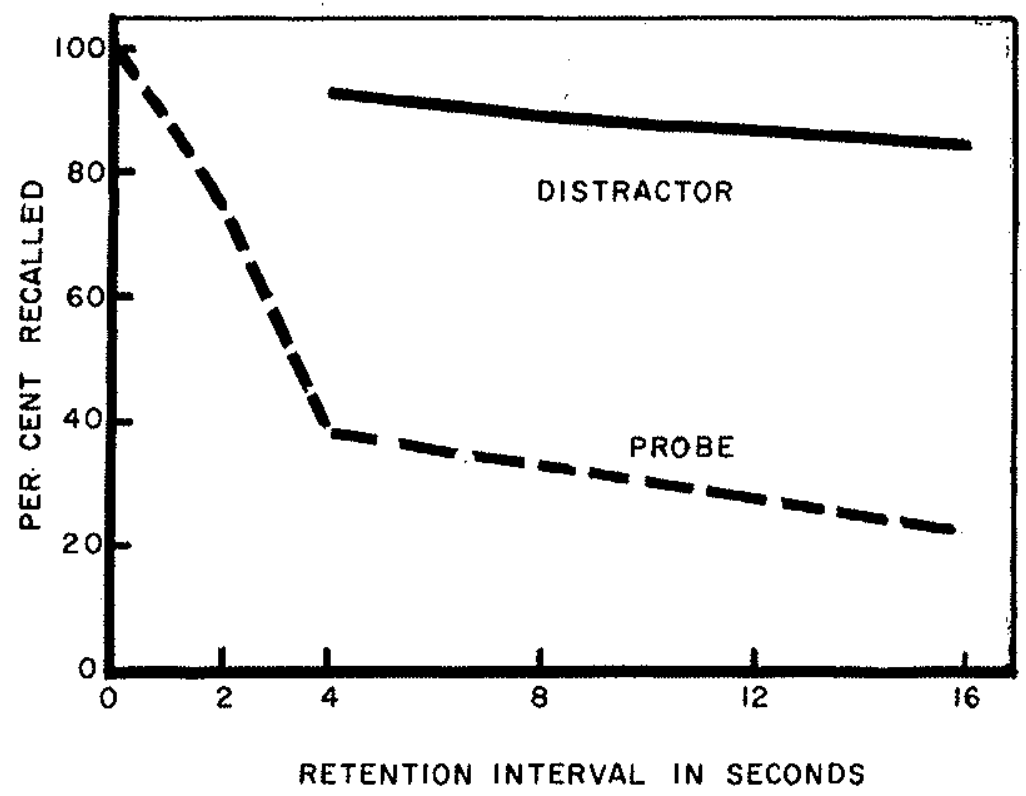

Figure 8. Retention curves obtained from the distractor and probe technique (redrawn from Keppel, 1965, pg 11, Figure 3).

short-term memory occurred between five and thirty seconds after one trial learning in this study.

Retrieval from short-term memory is a fairly simply process, not including any extensive formulation of functional units such as concepts and mnemonic connections. These functional units form in long-term memory as is explained in the section of this report dealing with mnemonics. Selzer and Wickelgren (1963) have described this retrieval process as being composed of two stages. The first stage, occurring within a few seconds after stimuli presentation, is a rapid ordered recall output of those items of which one is surest. The second stage occurring later when long-term memory is becoming a factor is a slower free recall output of those items which one thinks were probably in the sequence. 


\section{SECTION V \\ CONSOLIDATION OF LONG-TERM MEMORY}

Peterson (1966) has provided verbal learning data to support the contention that the long-term component increases in strength over time. He calls this process "reminiscence." The results show that the proportion of items correctly recalled increases (up to a point) with the duration of intervening digit-reading activity. In the case of the last digit in the series, a recency mechanism (short-term memory) contributed to a deterioration of the function until eight seconds of intervening digit counting activity had elapsed. Beyond eight seconds, growth (or consolidation) of the long-term memory component takes place. Different temporal gradients of retrograde amnesia produced by the convulsant drug, Metrazol, and electroconvulsive shock are shown in Figure 9 (Kincaid, 1968). Note that Metrazol produces retrograde amnesia when administered at a longer time after one trial passive avoidance training than is the case with electroconvulsive shock. However, Metrazol is a more severe amnesiac than electroconvulsive shock possibly because it affects the central nervous system for a longer time (at least ten seconds). Electroconvulsive shock was applied for only 0.3 seconds.

Alpern and Kimble (1967) have provided additional evidence that duration and intensity of treatment is directly related to degree of amnesic affect. Electroconvulsive shock stimulation that lasted 0.8 seconds of $8 \mathrm{ma}$. intensity produced retrograde amnesia when administered at a much longer interval after training than did stimulation that lasted 0.2 seconds of 15 ma. intensity. Peterson (1966) ascribed the decline during the first eight seconds to interference from earlier items; the rise in retention after eight seconds, he ascribed to an associative learning mechanism which increases in effectiveness with time. The consolidated association is more immune to interference than is the same item in short-term memory.

If the long-term memory function increases with time and if short-term memory initiates long-term memory, then manipulation of this two-part contingent process should affect consolidation of long-term memory. This 


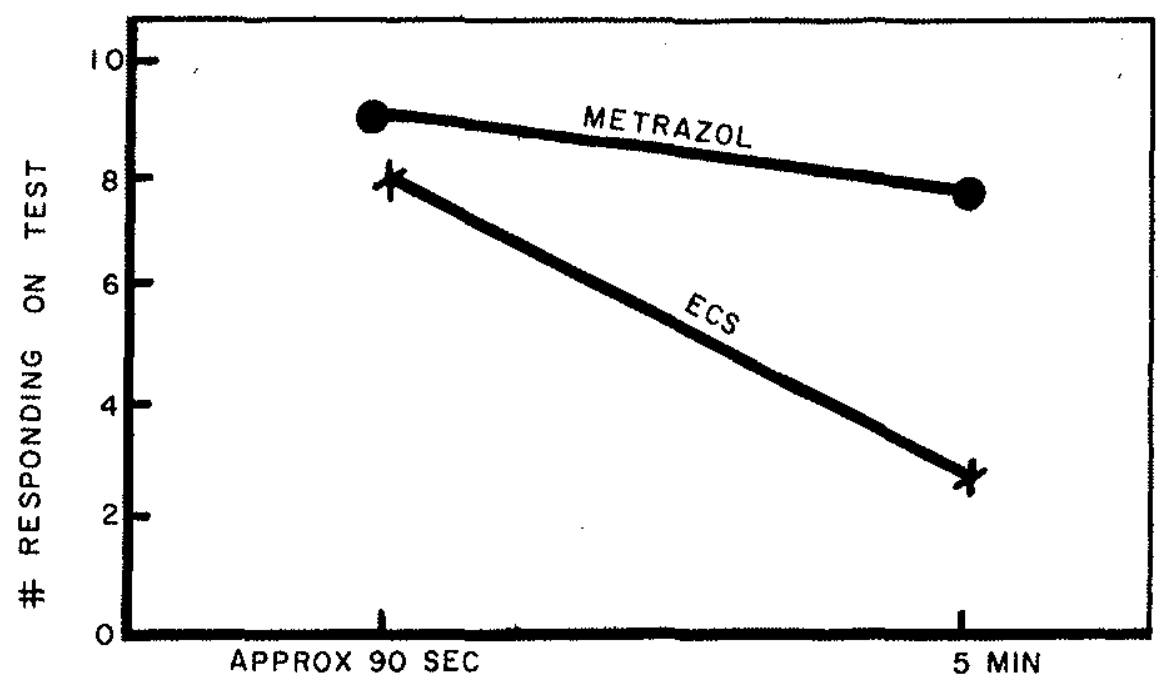

TIME BETWEEN PUNISHMENT AND CONVULSIVE TREATMENT

Figure 9. Temporal Gradients of Retrograde Amnesia Produced by Metrazol or Electroconvulsive Shock (Kincaid, 1968, Figure 1, pg 329)

is indeed the case, and two types of evidence are presented. The first type of evidence is that amnesiacs of various degrees of severity produce different temporal gradients of retrograde amnesia (e.g., Kincaid, 1968). The second type of evidence is that central nervous system stimulants such as picrotoxin and strychnine affect consolidation rate and consequently, learning ability (e.g., McGaugh, 1966).

Paolino, Quartermain, and Miller (1966) have demonstrated a less steep temporal gradient of retrograde amnesia produced by a several second application of $\mathrm{CO}_{2}$ than for a very brief application of electroconvulsive shock.

One explanation for these results is that these amnesic agents disrupt the short-term component of memory responsible for the initiation of long-term, consolidated memory. Long and short-term memory are considered to be overlapping processes and stronger amnesic agents can have an effect when administered at greater time periods from the learning trial because they are better able to interrupt the process whereby short-term memory initiates long-term memory. 
McGaugh (1966) describes a series of studies providing strong evidence that central nervous system stimulants can enhance memory consolidation. It has been found that central nervous system stimulants facilitate learning when administered either before or after the learning trial (Hunt and Krivanek, 1966). When the drug is administered before learning, the perceptual and motivational effects of the drug might have some bearing on the results. However, when the drug is administered after training, and the test is run after the effects of the drug have worn off, then the most likely explanation is that the drugs speeded consolidation. It is suggested that the drugs increased neural preservation (the basis of short-term memory) and that the consolidation of the neural trace (the basis of long-term memory) was more strongly initiated.

Several recent experiments have indicated that separate biochemical agents are responsible for trace storage and trace retrieval. The experiments involved extracting RNA (and other brain substances) from a donor trained to do a particular task and injecting it into a naive recipient. The hypothesis is that learning can be transferred in this way. Ungar and Irwin (1967), for example, transferred learning by transferring "trained" RNA between rodents. After first obtaining the natural bias of the donating subject (to eithex turn right or left in a maze) they trained him to turn either in the nonfavored or in the favored direction. Recipient subjects were also tested for directional preference. If the directional preference was the same for both donor and recipient, there was transfer of training; if the preferences were not the same, there was no transfer. The behavior of the subjects could be characterized as being influenced by a simultaneous transfer of both content information and retrieval messages. In other words, the two transferred messages were (a) turn in a particular direction, either left or right (storage information), and (b) turn against your natural preference (retrieval message). Thus, the separateness of trace storage and trace retrieval has been documented on a biochemical level. That trace storage and retrieval mechanisms can be distinguished behaviorally is documented in the next section. 


\section{SECTION VI}

\section{THE MORPHOLOGY OF LEARNING}

According to Deutsch (1968), the physiological basis of learning (long-term memory) is at present unknown. However, we are able to make some educated guesses. Halstead and Rucker (1969) define the consolidated engram as "the sum over space and time of changes in the operating characteristics of particular synapses between particular neurons." Rucker (personal communication) is of the opinion that individual neurons contribute component parts to the long-term trace. There are two types of evidence to support the belief that single cells perform the basic steps responsible for learning and memory. The first is that the rate of firing in individual neurons can be conditioned (Olds, 1965). The second is that individual one-celled animals can retain learning (McConnell, 1966).

If changes in individual neurons are responsible for long-term memory, then these changes contribute to the building of new neural networks. Further, according to Krech (1968), both RNA and enzymes contribute to these changes. For an excellent review of the biochemical mechanisms underlying memory, see Halstead and Rucker (1969). Figure 10 depicts the role of RNA and DNA in neural cell modifications which accompany learning.

While modifications in neural matrices are probably the basis of the formation of a new long-term memory and RNA and DNA play a role, enzymes also play a part. Acetylcholine (ACh) is necessary in order for neural impulses to be propagated across the junction between neurons (synapses). While ACh is necessary for neural transmission, when its concentration becomes too high, transmission is blocked. Another enzyme, acetylcholinesterase (AChE) is necessary to break down ACh after each neural transmission.

Deutsch (1968) has presented an interesting review describing how the manipulation of $\mathrm{ACh}$ and $\mathrm{AChE}$ by various drugs can alter memory and learning. Blocking agents (anticholenergics) and inhibitors (anticholinesterase) can each produce amnesia or facilitated recall depending upon the level of acetylcholine 


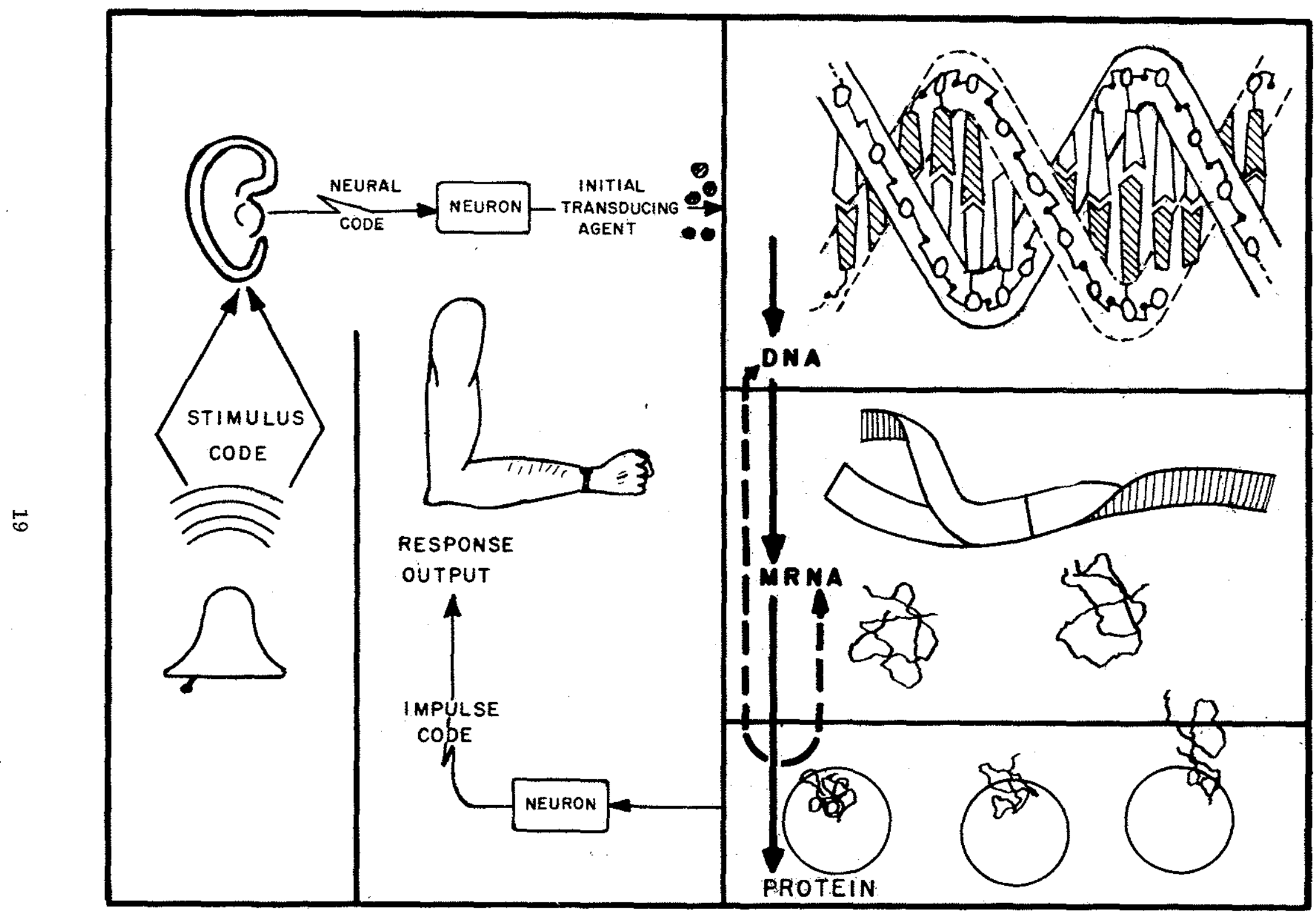

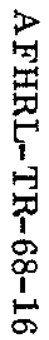

Figure 10. A molecular model of memory. This depicts permanent memory being stored in a feedback cycle involving protein synthesis. An incoming nerve impulse code triggers the release of an agent which in turn causes DNA to make RNA. The RNA directs the creation of new protein which modifies nerve cells causing learning (redrawn from Halstead and Rucker, 1968, pg 41), 
associated with a given learning and the effect of the injection of the particular drug on the acetylcholine level at that time. An example of a blocking agent that inhibits the action of $\mathrm{ACh}$ is scopolamine. In high doses, it completely blocks neural transmission. An example of an inhibiting agent that inhibits the action of AChE is diisopropyl fluorophosphate.

As is indicated in Figure 11, the degree of performance acquired by rats in a maze, is affected by the injecting of blocking or inhibiting agents. The balance between $\mathrm{ACh}$ and $\mathrm{AChE}$ must be within certain limits for firing across synapses to proceed properly and for memory of the learned event to be demonstrated. Any concentration of ACh above or below the critical range does not allow for proper neural transmission.

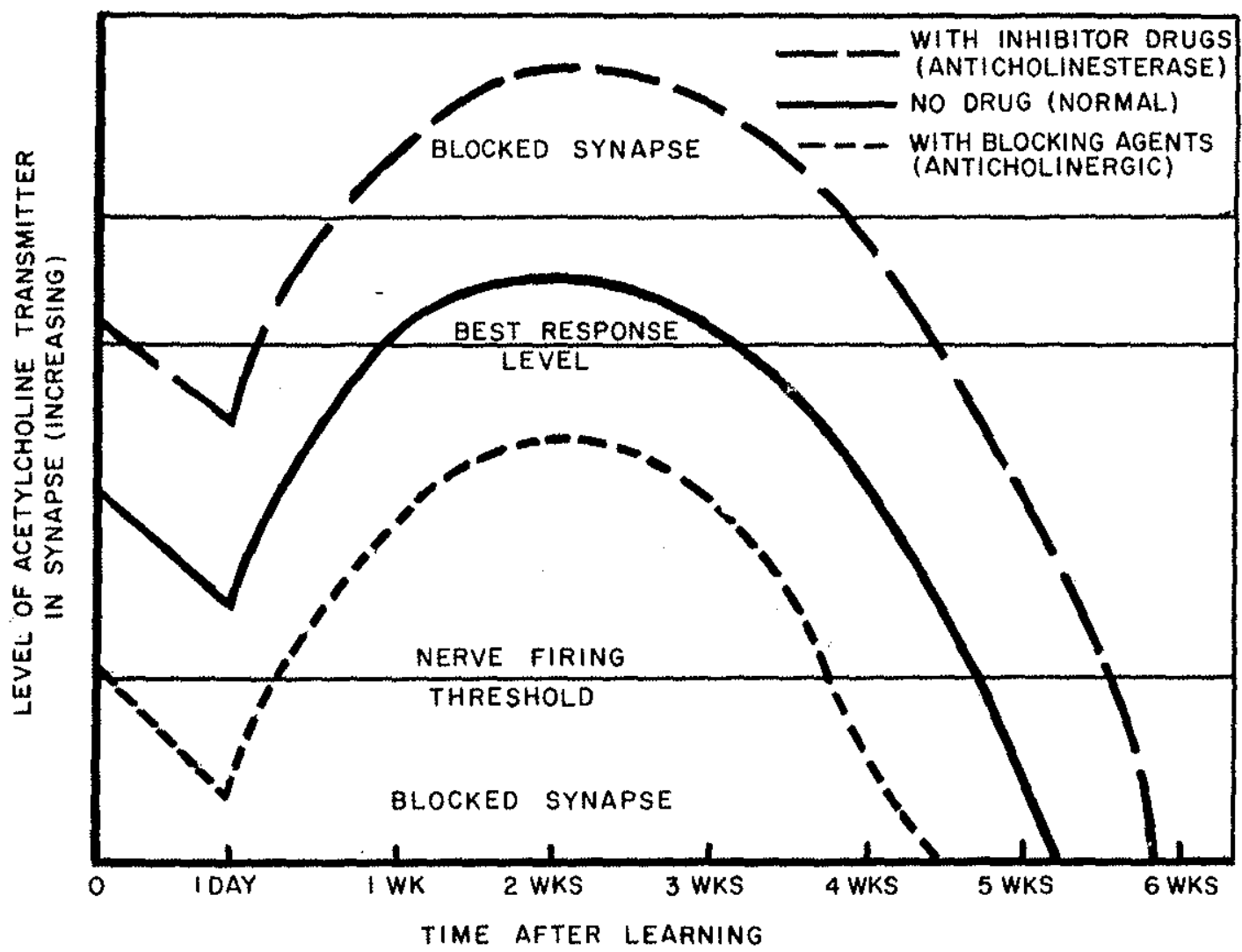

Figure 11. Changes in synapses after learning and the administration of drugs (redrawn from Deutsch, 1968, pg 60). 


\section{SECTION VII THE MECHANISMS OF MNEMONIC DEVICES}

For some time, both psychologists and laymen have been interested in the use of mnemonic devices to aid learning and remembering (James, 1890; Kay, 1888; Furst, 1957). This long continuing interest is reasonable because good retention of learned material is important in our classrooms and daily living. Basically, all mnemonic systems are based on a logical categorization of things to be remembered with things already firmly entrenched in memory. Furst (1957) has described this framework of existing memory as "hooks" onto which new material can be hung during the learning process. His technique, which involves the use of hooks, consists of a logical sequence of letters and numbers that must be completely committed to memory.

Recently, several investigators have examined the merits of mnemonic devices under rigorous experimental conditions (Smith and Noble, 1965; Senter, 1965; Senter and Hauser, 1968; Wood, 1967). In each case, the finding is that their use improves recall. The question is how and under what conditions do they work best.

Several recent articles (Slamecka, 1968; Tulving and Patterson, 1968; Glanzer and Cunitz, 1966) give us some insight into the mechanisms by which mnemonic devices work. While none of these experimental efforts is a direct test of the value of mnemonic devices, each helps to explain the process of operation in the two stages of memory. Each experimental effort utilized the free recall technique to determine if different mechanisms of storage (or retrieval) operate in long and short-term memory.

Glanzer and Cunitz (1966) concluded that the bimodel serial position curve in free recall is produced by separate long-term and short-term storage mechanisms. Tulving and Patterson (1968) demonstrated that functional grouping of related words occurs only when those words are retrieved from longterm memory. Slamecka (1968) concluded that words are stored independently of each other in long-term memory. These last two studies have obvious implications for the better use of mnemonic devices. If functional grouping of 
words occur only during retrieval from long-term memory and if words in long-term memory are stored separately, then mnemonic devices must be used in a certain way to be most effective. Sufficient time must be allowed for each mnemonic connection to reach long-term memory and the things to be remembered must be retrieved from long-term store. That is, they must be practiced. Nodine (1967) has also stressed the importance of a consideration of temporal variables when one is interested in understanding the mechanisms of concept formation. Concepts can be considered as nothing more than the formation of functional units in memory.

The experimental methodology used by Tulving and Patterson (1968) is worth examining in order to obtain empirical data on how long it takes from the time of learning until functional units (mnemonic connections) can be retrieved from long-term memory.

Tulving and Patterson (1968) used four serial lists of varying numbers of words (12 to 24 ) and presented the words at 1.5 second intervals. Two experimental conditions were used; one in which four word clusters (e.g., north, east, south, west) were presented either in the middle of the list or at the end. The four word group was distributed throughout the control group list. The most interesting finding of this effort was that the list in which the four word cluster appeared in the middle was retained better than the other two types of lists (when total number of words recalled was the measure of retention). However, if the cluster and each other word were each thought of as one functional unit, there was no difference in recall between the two experimental group lists. The time between the presentation of the four word cluster was the important factor. In the case in which the cluster was presented at the end of the list, recall came too soon (on the order of a few seconds) for that cluster to be recalled as a functional unit. However, when recall was delayed for 15 or 20 seconds, as was the case with the list in which the four word cluster appeared in the middle of the list, that cluster was recalled as a functional unit. Something happens in this instance to the encoding storage or retrieval mechanisms between 5 seconds and 15 seconds after presentation. The three models of memory discussed above (Waugh and Norman, 1965, see Figure 1; Peterson, 1966, see Figure 2; Halstead and Rucker, 1968, see Figure 3) indicate that within a few seconds after presentation,material is transferred 
from a short-term (primary) to a long-term (secondary) memory store. Peterson's (1966) and Halstead and Rucker's (1968) graphs indicate that this transfer could occur between 5 and 15 seconds after presentation. Wood (1967) has shown that mnemonic devices are much more effective when 5 seconds rather than 2 seconds are allowed between presentations. Whether 10 seconds (or more) should be allowed for maximum benefit is not yet known. If too long an interval is allowed before recall or covert rehearsal then the material might never get from short-term to long-term memory.

One thing that the models of memory largely overlook is the distinction that Melton (1963) makes among trace encoding, trace storage, and trace retrieval - they deal primarily with storage. Tulving and Patterson (1968) state that "a more appropriate view seems to be one according to which primary and secondary memory represents different types of retrieval mechanisms."

Slamecka (1968) has provided evidence that the formation of functional grouping of words is not a part of the storage mechanism of long-term memory and traces of words are stored independently. His procedure involved the use of serial lists. One group of subjects was used to recall all of the words using a free recall procedure. The other group was provided with some of the words. The hypothesis was that the words that were provided would act as cue words in storage, if indeed the traces of these stored words were not independent. Consequently, recall would be facilitated. There was no difference between these two groups indicating that storage of each work was independent. The conclusion was that functional groupings are formed only during retrieval.

These findings and the theoretical framework in which they have been discussed, are quite compatible with results now being obtained from a large scale, field test of mnemonic training of Air Force maintenance personnel. The results of this field test are that mnemonic training is most effective when several seconds are allowed for each mnemonic connection to be learned and when that mnemonic connection is overtly practiced. Practice has been shown to be absolutely necessary to the success of the training. Mnemonic connections are apparent only when they are retrieved from long-term memory. 
However, the way material is encoded should affect how it is handled in longterm memory.

Lewis, Miller, and Misanin (1968), using ECS, provide evidence that memory involving functional units is based on a different process than memory not involving functional units. Rat subjects familiar with a step down task showed no evidence of memory disruption due to ECS. If the ECS treatment is given after only one avoidance training trial, it does produce retrograde amnesia. The authors contend that prior familiarization permits a new memory (for foot shock) to integrate into an existing memory system and thus protects it from the inhibitory effects of ECS. The point is that given time (and prior familiarization), a new memory is integrated into an existing one. Whether or not a retrieval process is required for this integration however is hard to determine in this case. 


\section{SECTION VIII}

\section{A FUNCTIONAL MODEL OF MEMORY}

Presented in Figure 11 is a model of memory derived from the preceding sections of this report. Such a model should serve, not only to organize a body of basic research about memory, but also probe us to think about its application to the improvement of the human learning capacity. Learning is sometimes said to be a potential change in behavior brought about by practice. Learning is based on the long-term memory mechanism.

From a practical standpoint, a detailed knowledge about the encoding storage and retrieval mechanisms is very beneficial (e.g., in a training situation). In most cases, a memory that lasts no longer than the duration of short-term memory (about 30 seconds) is not very useful. An exception is illustrated by the short-term retention of a seven digit phone number - long enough to dial the number. But the permanent memory of an often dialed phone number certainly saves trouble. A detailed knowledge of short-term memory (and its encoding mechanisms) is important to the extent that shortterm memory initiates long-term memory. Consequently, the psychologist or educator concerned with improving human learning or skill retention benefits from a knowledge of both long and short-term memory mechanism.

This report has two major themes. The first is the construction of the model of memory presented in Figure 12 which is based on evidence presented in earlier sections. This evidence supported the following conclusions: (a) Short-term memory and long-term memory are distinguishable processes.

(b) Short-term memory initiates long-term memory. (c) Short-term memory is characterized by autonomous decay, distortion by interference, and a limited capacity. (d) Long-term memory is mediated by a consolidation process dependent upon certain enzymes and structural changes produced by RNA. (e) Learning in the traditional sense, can take place only if a memory reaches long-term memory. (f) Functional grouping of items in memory (the basis of effective learning) can take place during recall from long-term memory. (g) Consolidated memories that are reactivated are brought into 


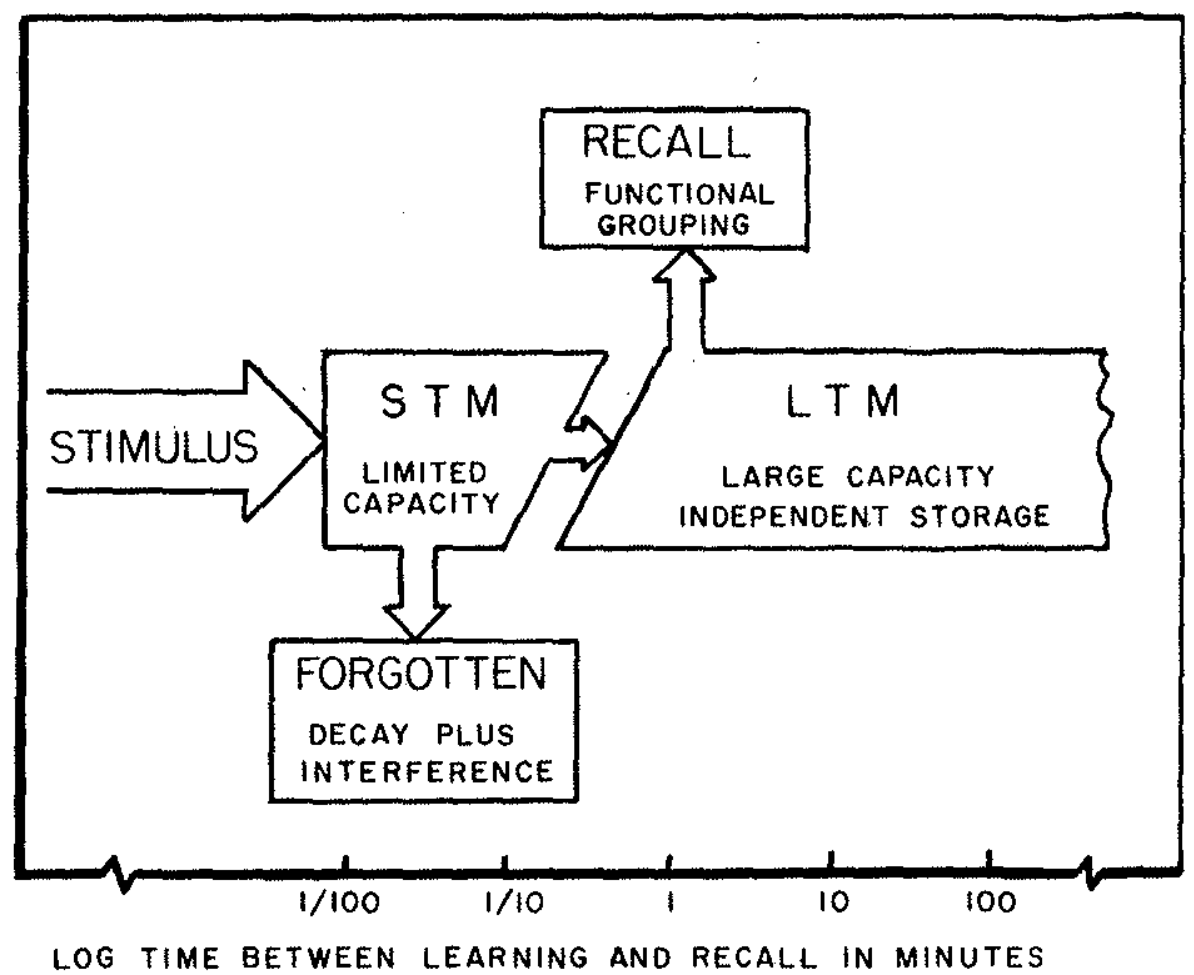

Figure 12. A Functional Model of Memory

the short-term memory mechanism. The time courses of long and short-term memory are also described in Figure 12.

The second major theme of this report is the need to use the constructed model of memory or any model of memory in a functional way. An attempt was made to describe how mnemonic devices work within the constraints imposed by the model. Mnemonic connections occur during recall, if recall is delayed for about five seconds.

As is the case with any review article, this report would certainly not be complete without some suggestions about future research needs. We need to know more about the interface between short-term memory and long-term memory, particularly how encoding of information takes place. We need to know more about the time course of both short-term memory and long-term memory and how various situations (difficulty of task, innate intelligence of the subject, drugs, etc.) affect this time course. We need to know more about 
how RNA and enzymes affect the structure of neurons involved in long-term memory. We need to know more about how mnemonic systems work. And finally, we need to direct the insights gained from a study of these (and other) problem areas toward the improvement of human learning capabilities. 


\section{REFERENCES}

Alluisi, E. A., Strain, G. S., and Thurmond, J. B., "Stimulus-Response Compatibility and the Rate of Gain of Information." Psychonomic Science, 1964,1, 111-112.

Alpern, H. P. and Kimble, D. P., "Retrograde Amnesic Effects of Diethyl Ether and Bis(trifluorethyl) Ether." Journal of Comparative and Physiological Psychology $_{2}$ 1967, 63, 168-171.

Batten, D. E., "Recall of Paired Associates as a Function of Arousal and Recall Interval." Perceptual and Motor Skills, 1967, 24, 1055, 1058.

Berlyne, D. E., Borsa, Donna M., Hamacher, Jane H., and Koenig, I. D. V., "Paired-Associate Learning and the Timing of Arousal." Journal of Experimental Psychology, 1966, 72, 1-6.

Chevalier, J. A., "Permanence of Amnesia After A Single Posttrial Electroconvulsive Seizure." Journal of Comparative and Physiological Psychology, $1965,59,125-127$.

Chorover, S. L., and Schiller, P. H., "Reexamination of Prolonged Retrograde Amnesia in One Trial Training." Journal of Comparative and Physiological Psychology, 1966, 61, 34-41.

Collins, A. M., and Quillian, M. R., Retrieval Time From Semantic Memory. Report No. 1692, Bolt, Beranek, and Newman, Inc.

Deutsch, J. A., "Neural Basis of Memoxy." Psychology Today, 1968, 1, 56-61.

Estes, W. K., "Statistical Theory of Distributional Phenomena in Learning." Psychological Review, 1955, 62, 369-377.

Furst, B., The Practical Way to a Better Memory. New York: Fawcett World Library, 1957.

Glanzer, M. and Cunitz, Anita R., "Two Storage Mechanisms in Free Recall." Journal of Verbal Learning and Verbal Behavior, 1966, 5, 351-360.

Halstead, W. C. and Rucker, W. B., "Memory: A Molecular Maze." Psychology_ Today, June 1968, 38-42 and 65-68.

Halstead, W. C. and Rucker, W. B., The Molecular Biology of Memory. In Byrne, W. (Ed). Molecular Approaches to Learning and Memory, 1969, New York Academic Press (in press).

Hunt, E. B. and Krivanek, J., Psychopharalogiea, 1966.

James, W., Principles of Psychology. New York: Holt, 1890. 


\section{REFERENCES (Contd)}

Kay, D., Memory: What It Is And How To Improve It. London: Kegan Paul, Trench, 1888.

Keppel, G., "Problems of Methods in the Study of Short-Term Memory." Psychological Bulletin, 1965, 63, 1-13.

Keppe1, G. and Underwood, B. J., Proactive Inhibition in Short-Term Retention of Single Items, Journal of Verbal Learning and Verbal Behavior, 1962, 1, 153-161.

Kincaid, J. P., "Permanence of Amnesia After Single Posttrial Treatments of Metrazol or Electroconvulsive Shock." Psychonomic Science, 1967, 9, $59-60$.

Kincaid, J. P., "Different Temporal Gradients of Retrograde Amnesia Produced by Metrazol or Electroconvulsive Shock." Psychonomic Science, 1968, $11,329-330$.

Kleinsmith. L. J. and Kaplan, S., "Interaction of Arousal and Recall Interval in Nonsense Syllable Pair-Associates Learning." Journal of Experimental Psychology, 1964, 67, 124-126.

Kohlenberg, R. and Trabasso, T., "Recovery of a Conditional Emotional Response After One or Two Electroconvulsive Shocks." Journal of Comparative and Physiological Psychology, 1968, 65, 270-273.

Krech, D., "The Chemistry of Learning." Saturday Review, January 20, 1968, pg 48-50 and 68.

Lewis, D. J., Miller, R. R., and Misanin, J. R., "The Control of Retrograde Amnesia"'. Journal of Comparative and Physiological Psychology, 1969 (in press.)

Loess, H., "Proactive Inhibition in Short-Term Memory."' Journal of Verbal Learning and Verbal Behavior, 1964, 3, 362-368.

McConnell, J. V., "Comparative Physiology: Learning in Invertebrates." Annual Review of Physiology, 1966, 28, 107-136.

McGaugh, J. L., "Facilitative and Dismuptive Effects of Strychnine Sulphate on Maze Learning." Psychological Reports, 1961, 8, 99-104.

McGaugh, J. L., "Time-Dependent Processes in Memory Storage." Science, $1966,153,1351-1358$.

Melton, A. W., "Implications of Short-Term Memory for a General Theory of Memory." Journal of Verbal Learning and Verbal Behavior, 1963, 2, 1-21. 
REFERENCES (Contd)

Miller, G. A., "The Magical Number Seven, Plus or Minus Two: Some Limits on Our Capacity for Information Processing." Psychological Review, 1956, $63,81-97$.

Misanin, J. R., Miller, R. R., and Lewis, D. J., "Retrograde Amnesia Produced by Electroconvulsive Shock and Reactivation of a Consolidated Memory Trace." Science, 1968, 160, 554-555.

Murdock, B. B., "Measurement of Retention of Interpolated Activity in ShortTerm Memory." Journal of Verbal Learning and Verbal Behavior, 1966, 5, 469-472.

Murdock, B. B., "Distractor and Probe Techniques in Short-Term Memory." Canadian Journal of Psychology, 1967, 21, 25-35.

Murdock, B. B., "Serial Order Effects in Short-Term Memory." Journal of Experimental Psychology Monograph Supplement, 1968, 76, whole No. 4, Part 2.

Nodine, C. F., The Role of Temporal Variables in the Acquisition of Concepts. in B. Kleinmuntz (Ed.), Concepts and the Structure of Memory. New York: Wiley, 1967.

Olds, J., "Operant Conditioning of Single Unit Responses." Excerpta Medica International Congress Series. 1965

Paolino, R. M., Quartermain, D., and Miller, N.E, "Different Temporal Gradients of Retrograde Amnesia Produced by Carbon Dioxide Anesthesia and Electroconvulsive Shock." Journal of Comparative and Physiological Psychology, 1966, 62, 270-274.

Peterson, L. R., Short-Term Verbal Memory and Learning," Psychological Review, 1966, 73, 193-207.

Peterson, L. R., "Reminiscence in Short-Term Retention." Journal of Experimental Psychology, 1966, 71, 115-118 (a).

Peterson, L. R. and Peterson, M. J., "Short-Term Retention of Individual Verbal Items. Journal of Experimental Psychology, 1962, 63, 521-527.

Quartermain, D., Paolino, R. M., and Miller, N. E., "A Brief Temporal Gradient of Retrograde Amnesia Independent of Situational Change." Journal of Comparative and Physiological Psychology, 1965, 149, 1116-1118.

Schneider, A. M., Sherman, W., Amnesia: A Function of the Temporal Relation of Footshock to Electroconvulsive Shock. Science, 1968, 159, 219-221.

Senter, R. J., Review of Mnemonics and Mnemonontechnics for Improved Memory. Wright-Patterson Air Force Base, Ohio: Aerospace Medical Research Laboratories, 1965, (AMRL-TR-65-180). 


\section{REFERENCES (Concld)}

Senter, R. J. and Hauser, G. K., "An Experimental Study of a Mnemonic System." Psychonomic Science, 1968, 10, 289-290.

Slamecka, N. J., "An Examination of Trace Storage in Free Recall." Journal of Experimental Psychology, 1968, 76, 504-513.

Smith, R. K. and Noble, C. E., "Effects of a Mnemonic Technique Applied to Verbal Learning and Memory." Perceptual and Motor Skills, 1965, 21, 123-134.

Tulving, E. and Patterson R. D., "Functional Units and Retrieval Processes in Free Recall." Journal of Experimental Psychology, 1968, 77, 239-248.

Ungar, G. and Irwin, L. N., "Transfer of Acquired Information by Brain Extracts." Nature, 1967, 214, 453-455.

Waugh, Nancy C. and Norman, D. A., "Primary Memory." Psychological Review, 1965, 72, 89-104.

Weiner, B. and Walker, E. L., "Motivational Factors in Short-Term Retention." Journal of Experimental Psychology, 1966, 71, 190-193.

Wickelgren, W. A., 'Associative Intrusions in Short-Term Recall." Journal of Experimental Psychology, 1966, 72, 853-858.

Wickelgren, W. A., "Rehearsal Grouping and Hierarchical Organization of Serial Position Cues in Short-Term Memory." The Quarterly Journal of Experimental Psychology, 1967, 19, 97-102.

Wickens, D. D., Born, D. G., and Allen, C. K., "Proactive Inhibition in ShortTerm Memory." Journal of Verbal Learning and Verbal Behavior, 1963, 2, $440-445$.

Wood, G., Mnemonic Systems in Recall." J. of Educational Psychology Monograph, 1967, 58. 


\section{DOCUMENT CONTROL DATA - R\&D}

(Security classification of titlo, body ol abstract and indoxing ennotation must bo onterod when the overell report is classilied) 1. ORIGINATING ACTIVITY (Corpotato author)

Air Force Human Resources Laboratory

Air Force Systems Command

Wright-Patterson Air Force Base, Ohio 45433

3. REPORT TITLE

\section{A FUNCTIONAL MODEL OF MEMORY BASED ON PHYSIOLOGICAL AND} VERBAL LEARNING DATA

4. DESCRIPTIVE NOTES (Typo of roport and inclusivo datos)

Work period from June 1968 through August 1968.

5. AUTHOA(S) (Laet name, firat namo, initial)

Kincaid, Peter J.

\begin{tabular}{|c|c|c|}
\hline $\begin{array}{l}\text { 6. REPORT DATE } \\
\text { April } 1969\end{array}$ & $\begin{array}{c}\text { 7a. TOTAL NO. OF PAGES } \\
40\end{array}$ & $\begin{array}{c}\text { 7b. NO. OF REFS } \\
54\end{array}$ \\
\hline $\begin{array}{l}\text { Ba. CONTRACT OR GRANT NO. } \\
\text { b. PROJECT NO. } 7907\end{array}$ & \multicolumn{2}{|c|}{$\begin{array}{l}\text { 9a. ORIGINATOR'S REPORT NUMBER(S) } \\
\text { AFHRL-TR-68-16 }\end{array}$} \\
\hline c. & \multicolumn{2}{|c|}{$\begin{array}{l}\text { Sb. OTHER REPORT NO(S) (Any othor numbers that may bo as al aned } \\
\text { this report) }\end{array}$} \\
\hline \multicolumn{3}{|c|}{$\begin{array}{l}\text { 10. AVA ILABILITY/LIMITATION NOTICES } \\
\text { This document has been approved for public release and sale; its distribution is } \\
\text { unlimited. }\end{array}$} \\
\hline 11. SUPPL EMEN TARY NOTES & \multicolumn{2}{|c|}{$\begin{array}{l}\text { 12. SPONSORING MILITARY ACTIVITY } \\
\text { Air Force Human Resources Laboratory } \\
\text { Wright-Patterson Air Force Base, Ohio } 45439\end{array}$} \\
\hline
\end{tabular}

13. ABSTRACT

This report presents a functional model of memory based on verbal learning and physiological data. These diverse empirical data are used to describe several basic mechanisms of memory including: (a) separate mechanisms for short-term memory and for long-term memory; (b) the initiation of long-term memory by short-3termi memory; (c) the properties of short-term memory including autonomous decay, distortion by interference, and a limited capacity; (d) the properties of long-term memory including a consolidation process dependent upon ribonucleic acid (RNA) and enzymes, and a very large capacity; (e) the functional grouping of items in long-term memory; and (f) consolidated (long-term) memories that are reactivated, being brought back into short-term memory. Time courses of these events are described. The ultimate benefits of a detailed knowledge of the mechanisms of memory is to help us to better understand how humans learn. This report describes how mnemonic techniques work and presents suggestions about how to improve memory training. 
UNCLASSIFIED

Security Classification

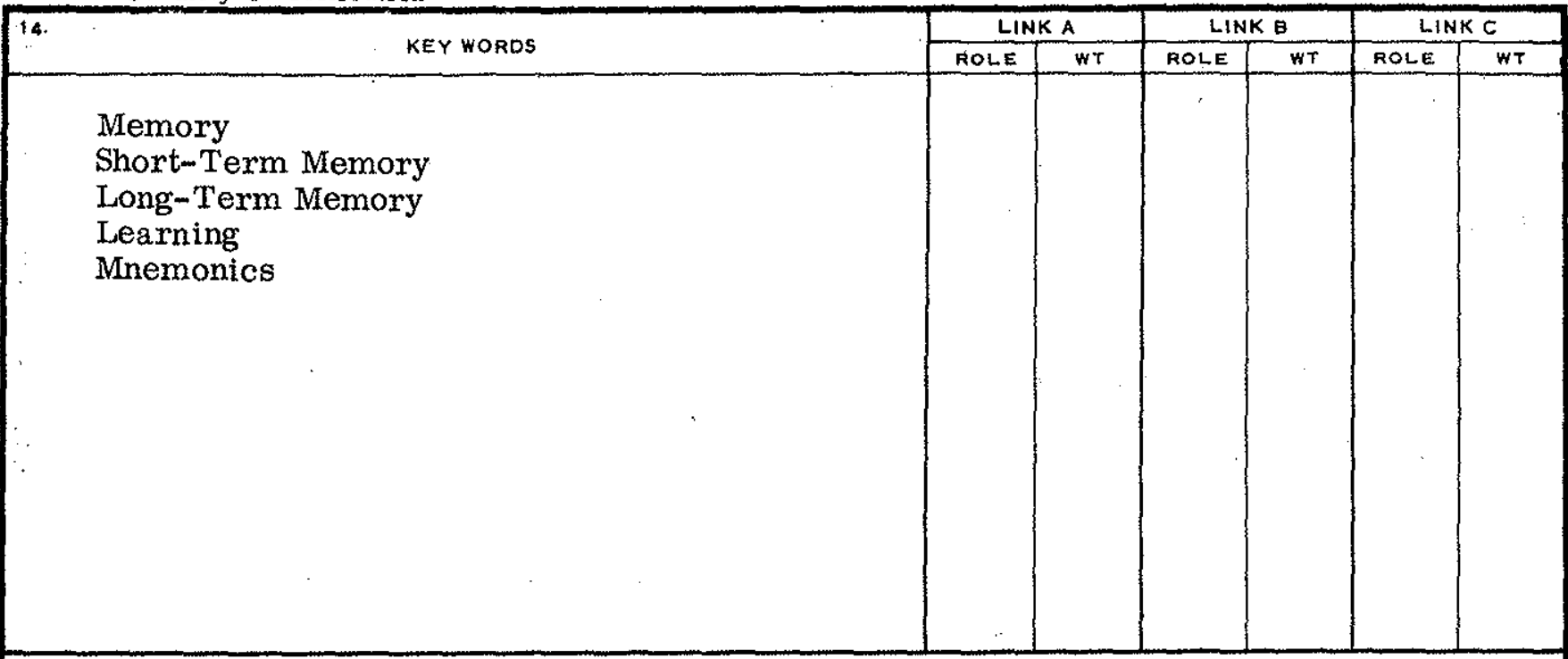

\section{INSTRUCTIONS}

1. ORIGINATING ACTIVITY: Enter the name and address of the contractor, subcontractor, grantee, Department of Defense activity or other organization (corporate author) issuing the report.

2a. REPORT SECURTY CLASSIFICATION: Enter the overall security classification of the report. Indic ate whether "Restricted Data" is included Marking is to be in accord ance with appropriate security regulations.

2b. GROUP: Automatic downgrading is specified in DoD Directive 5200.10 and Armed Forces Industrial Manual. Enter the group number. Also, when applicable, show that optional markings have been used for Group 3 and Group 4 as authorized.

3. REPORT TITLE: Enter the complete report title in all capital letters. Titles in all cases should be unclassified. If a meaningful title cannot be selected without classification, show title classification in all capitals in parenthesis immediately following the title.

4. DESCRIPTIVE NOTES: If appropriate, enter the type of report, e.g., interim, progress, summary, annual, or final. Give the inclusive dates when a specific reporting period is covered.

5. AUTHOR(S): Enter the name(s) of author(s) as shown on or in the report. Ent er last name, first name, middle initial. If military, show rank and branch of service. The name of the principal asthor is an absolute minimum requirement. 6. REPORT DATE: Enter the date of the report as day, month, year; or month, year. If more than one date appears on the report, use date of publication.

7a. TOTAL NUMBER OF PAGES: The total page count should follow normal pagination procedures, $i$, e., enter the number of pages containing information.

7b. NUMBER OF REFERENCES: Enter the total number of references cited in the report.

8 a. CONTRACT OR GRANT NUMBER: If appropriate, enter the applicable number of the conttact or grant under which the report was written.

$8 b, \&, \& 8 d$. PROJECT NUMBER: Enter the appropriate military department identification, such as project number, subproject number, system numbers, task number, etc.

9a. ORIGINATOR'S REPORT NUMBER(S): Enter the official teport number by which the document will be ident ified and controlled by the originating activity. This number must be unique to this report.

9b. OTHER REPOR' NUMBER(S): if the report has been assigned any other report numbers (either by the originator or by the sponsor), also enter this number(s).

10. AVAIL ABILITY/LIMITATION NOTICES: Enter any limitations on further dissemination of the report, other than those imposed by security classification, using standard statements such as:

(1) "Qualified requesters may obtain copies of this report from $\mathrm{DDC}$ ผ

(2) "Foreign announcement and dissemination of this report by DDC is not authorized."

(3) "U. S. Government agencie's may obtain copies of this report directly from DDC. Other qualified DDC users shall request through

(4). "U. S. military agencies may obtain copies of this report directly from DDC. Other qualified users shall request through

".

(5) "All distribution of this report is controlled. Qual. ified DDC users shall request through "

If the report has been furnished to the Office of Technical Services, Department of Commerce, for sale to the public, indicate this fact and enter the price, if known.

11. SUPPLEMENTARY NOTES: Use for additional explanatory notes.

12. SPONSO : 1 NG MILITARY ACTIVTTY: Enter the name of the departmental project office or laboratory sponsoring (pay ing for) the research and development. Include address.

13. ABSTRACT: Enter an abstract giving a brief and factual summary of the document indicative of the report, even though it may also appear elsewhere in the body of the technical report. If additional space is required, a continuation sheet shall be attached.

It is highly desirable that the abstract of classified reports be unclassified. Each paragraph of the abstract shall end with an indication of the military security classification of the information in the paragraph, represented as (TS), (S), (C), or (U).

There is no limitation on the length of the abstract. However, the suggested length is from 150 to 225 words.

14. KEY WORDS: Key words are technically meaningful terms or short phrases that characterize a report and may be used as index entries for cataloging the report. Key words must be selected so that no security classification is required. Identifiers, such as equipment model designation, trade name, military project code name, geographic location, may be used as key words but will be followed by an indication of technical con. text. The assignment of links, rules, and weights is optional. 